\section{International Scientific Journal Theoretical \& Applied Science}

p-ISSN: $2308-4944$ (print)

e-ISSN: 2409-0085 (online)

Year: 2017

Issue: 03

Volume: 47

Published: 4.03 .2017

http://T-Science.org

SECTION 4. Computer science, computer engineering and automation.
Alexandr Shevtsov

candidate of technical sciences, member of PILA (USA), member of European Academy of Natural History (UK), member of Federation of Robotics Kazakhstan, Department of «Mathematics», Deputy Director on Science of faculty of information technologies, automation and telecommunications,

Taraz state University named after M.Kh. Dulati $\underline{\text { Shev_AlexXXXX@mail.ru }}$

Nargiza Talaybekkyzy researcher,

Taraz state University named after M.Kh. Dulati, KZ ntalaybekkyzy@mail.ru

\title{
DEVELOPMENT OF AUTONOMOUS ROBOT FOR RADIATION RECONNAISSANCE
}

Abstract: In this work, we developed algorithms for simulating the actions of Autonomous robot detecting radioactive contamination in inaccessible places. Developed algorithms for remote robot control. The resulting algorithms are tested and implemented on a real robotic platform. Also developed a program for the Arduino microprocessor to control a fully assembled robot, and automated actions according to algorithms or remote control.

Key words: program, radiation, robot.

Language: English

Citation: Shevtsov A, Talaybekkyzy N (2017) DEVELOPMENT OF AUTONOMOUS ROBOT FOR RADIATION RECONNAISSANCE. ISJ Theoretical \& Applied Science, 03 (47): 1-4.

Soi: http://s-o-i.org/1.1/TAS-03-47-1 Doi: crossef https://dx.doi.org/10.15863/TAS.2017.03.47.1

\section{Introduction}

In this work, we developed the mobile robot and the search engine algorithms places of contamination by radioactive particles.

Made testing of the proposed algorithms on a real robot. The algorithms remote control, radiation sensing area and the decision depending on the received data. As well as the possibility of using a robot to analyze the air to determine the temperature and humidity.

The aim of the study was to Develop a mobile robot for radiation detection.

Urgency: the Developed algorithms are of practical importance and relevance, and can find application in military robotics, as well as for local contamination by radioactive materials.

Novelty: Designed an Autonomous robot that implements the search algorithms of radioactive contamination and perform a specific action that accelerates the process of infection. The resulting algorithms tested on self-assembled robot on the Arduino's microcontroller.

\section{Materials and Methods}

Implementation of the project:

This work is dedicated to the development and implementation of the search algorithm of radiation contamination. Statement of the problem in the General case is implemented in several stages:

- Build a mobile robot from components

- Development of algorithms for remote control based on Bluetooth,

- The study and use of radiation sensor,

- Mathematical simulation of algorithms for independent decision-making robot

- Testing of mathematical algorithms and robot

Build a mobile robot from components:

- The Assembly robot will be implemented based on the microcontroller ArduinoUno, control leading drivers - driver L298N and a radiation sensor.

- Develop the concept of the robot: In will be based on the ArduinoUno.

- For rapid detection of objects emitting radiation place the sensor on the robot Geiger Tube M4011. 


\begin{tabular}{|c|c|c|c|c|c|c|}
\hline Impact Factor: & $\begin{array}{l}\text { ISRA (India) } \\
\text { ISI (Dubai, UAE } \\
\text { GIF (Australia) } \\
\text { JIF }\end{array}$ & $\begin{array}{l}=1.344 \\
=0.829 \\
=0.564 \\
=1.500\end{array}$ & $\begin{array}{l}\text { SIS (USA) } \\
\text { PИНЦ (Russia) } \\
\text { ESJI (KZ) } \\
\text { SJIF (Morocco) }\end{array}$ & $\begin{array}{l}=0.912 \\
=0.234 \\
=1.042 \\
=2.031\end{array}$ & $\begin{array}{l}\text { ICV (Poland) } \\
\text { PIF (India) } \\
\text { IBI (India) }\end{array}$ & $\begin{array}{l}=6.630 \\
=1.940 \\
=4.260\end{array}$ \\
\hline
\end{tabular}

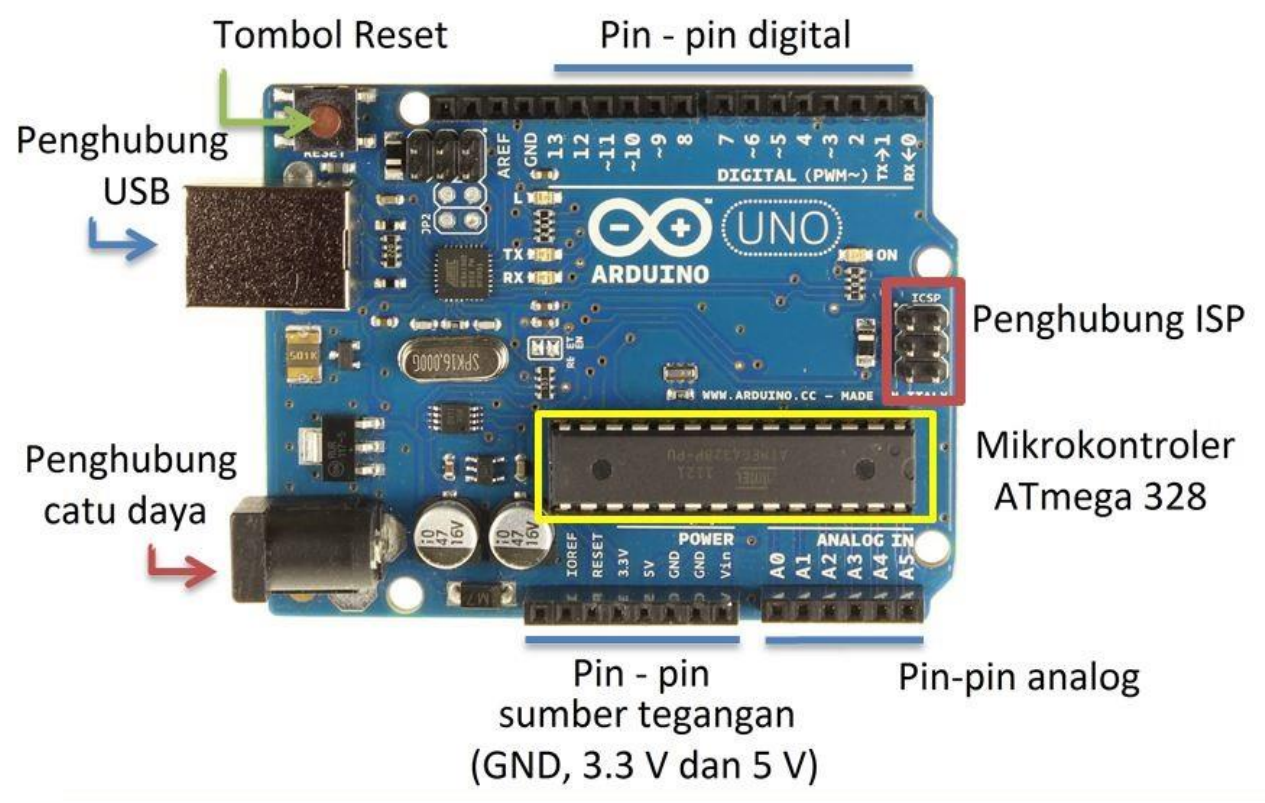

Picture 1 - Arduino Uno.

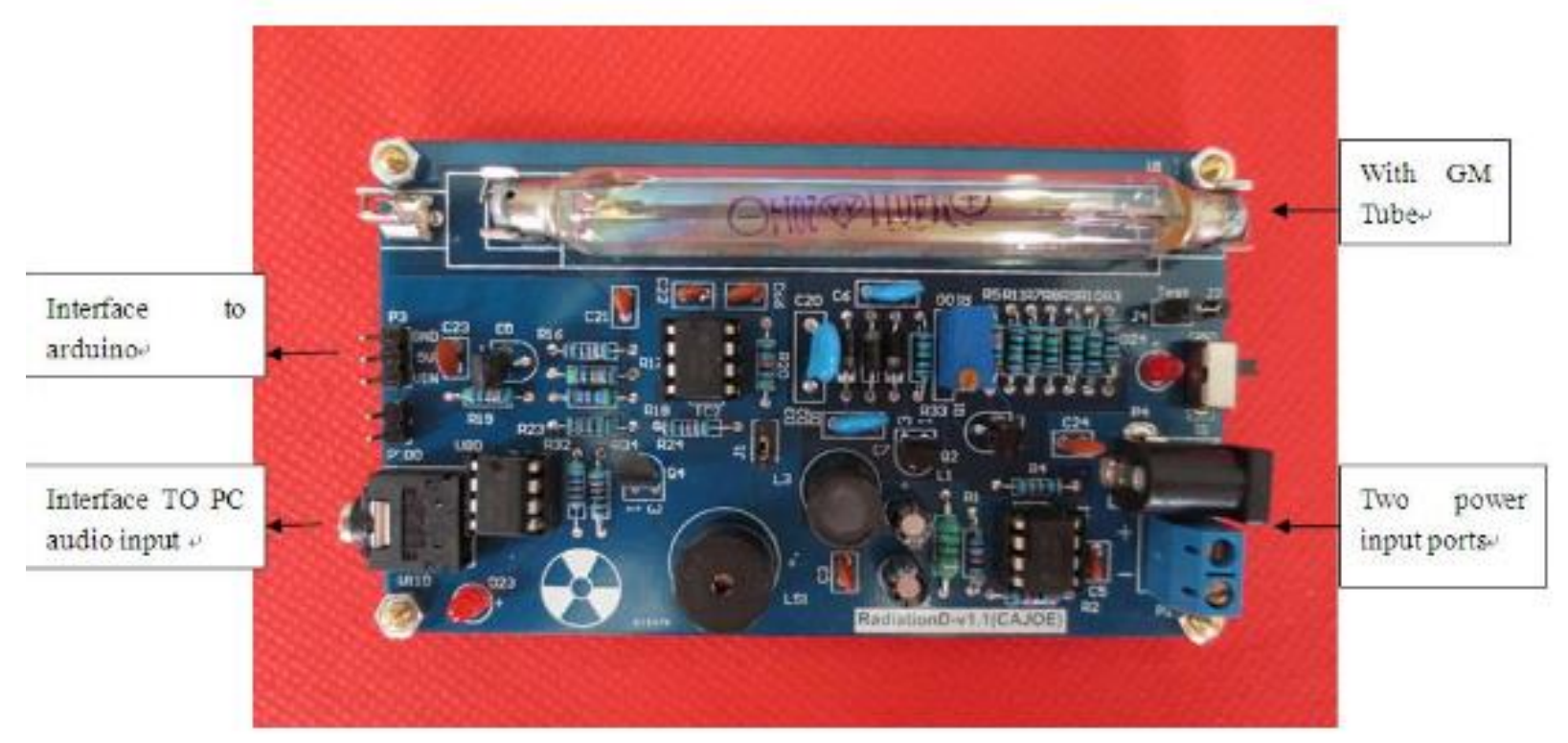

Picture 2 - Geiger Tube M4011.

Specification of the Geiger Tube M4011:

- tin oxide Cathode, a coaxial cylindrical thin body structure (Wall density is $50 \pm 10 \mathrm{cg} / \mathrm{cm} 2)$, the use of pulse-type halogen tube

- application temperature: $-40^{\circ} \mathrm{C} \sim 55^{\circ} \mathrm{C}$

- can be used for: $\gamma$ Ray $20 \mathrm{mR} / \mathrm{h} \sim 120 \mathrm{mR} / \mathrm{h}$

- $\beta$ Rays in the range of $100 \sim 1800$ ChangingIndex/min · CM 2 soft $\beta$ Rays
- (as beta-and gamma-radiation detetion)

- working Voltage: 380-450 In

- working Current: 0,015-0,02 mA

- sensitivity to Gamma Radiation: $0.1 \mathrm{MeV}$

- own Background: 0,2 Pulses/s

- length: $88 \mathrm{~mm}$

- diameter: $10 \mathrm{~mm}$ 


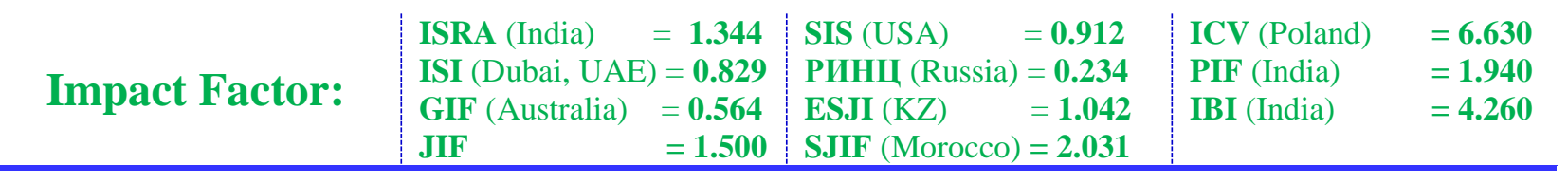

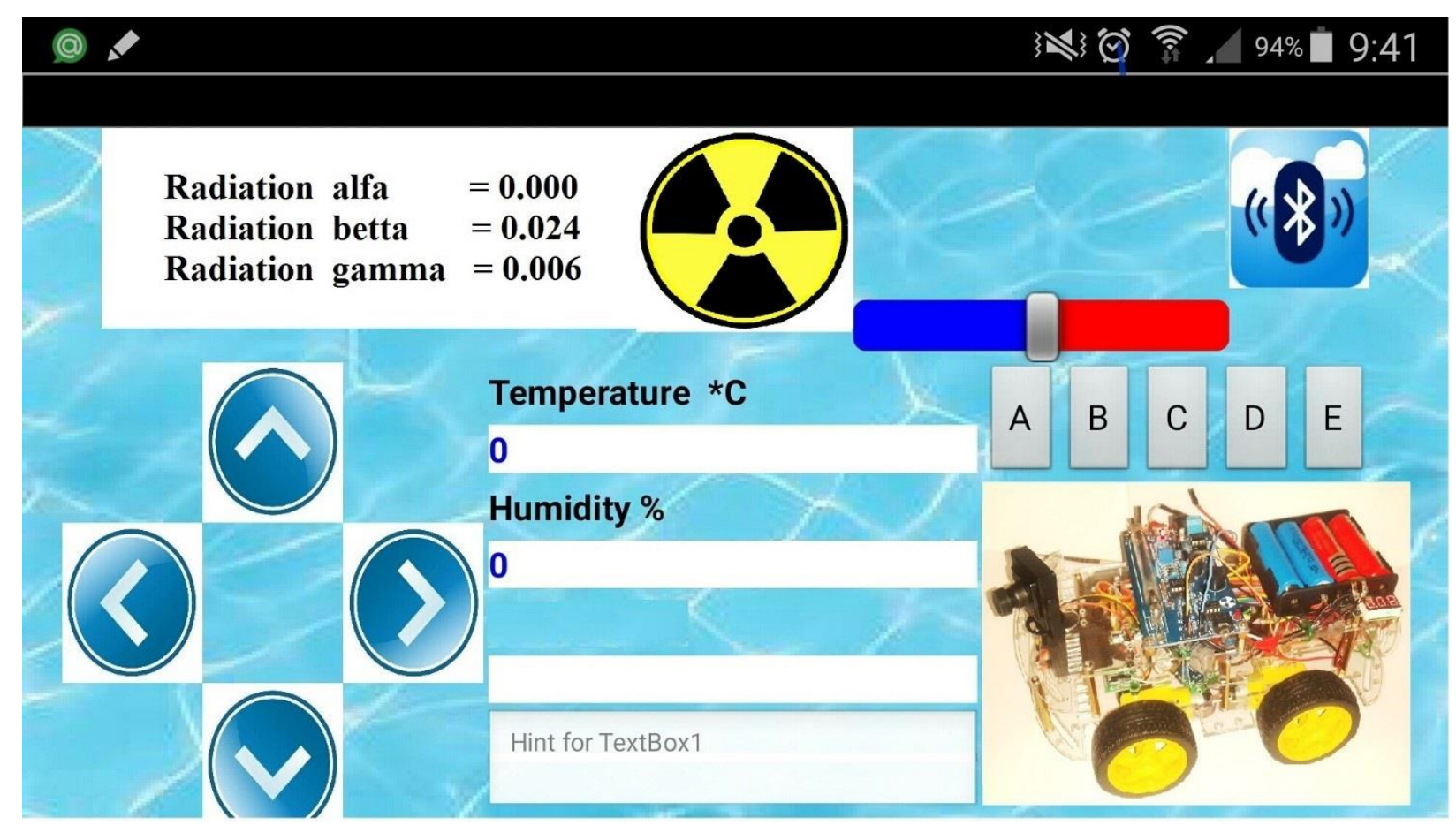

Picture 3 - The robot control program for smartphone based on Android and receive data from the Geiger tube.

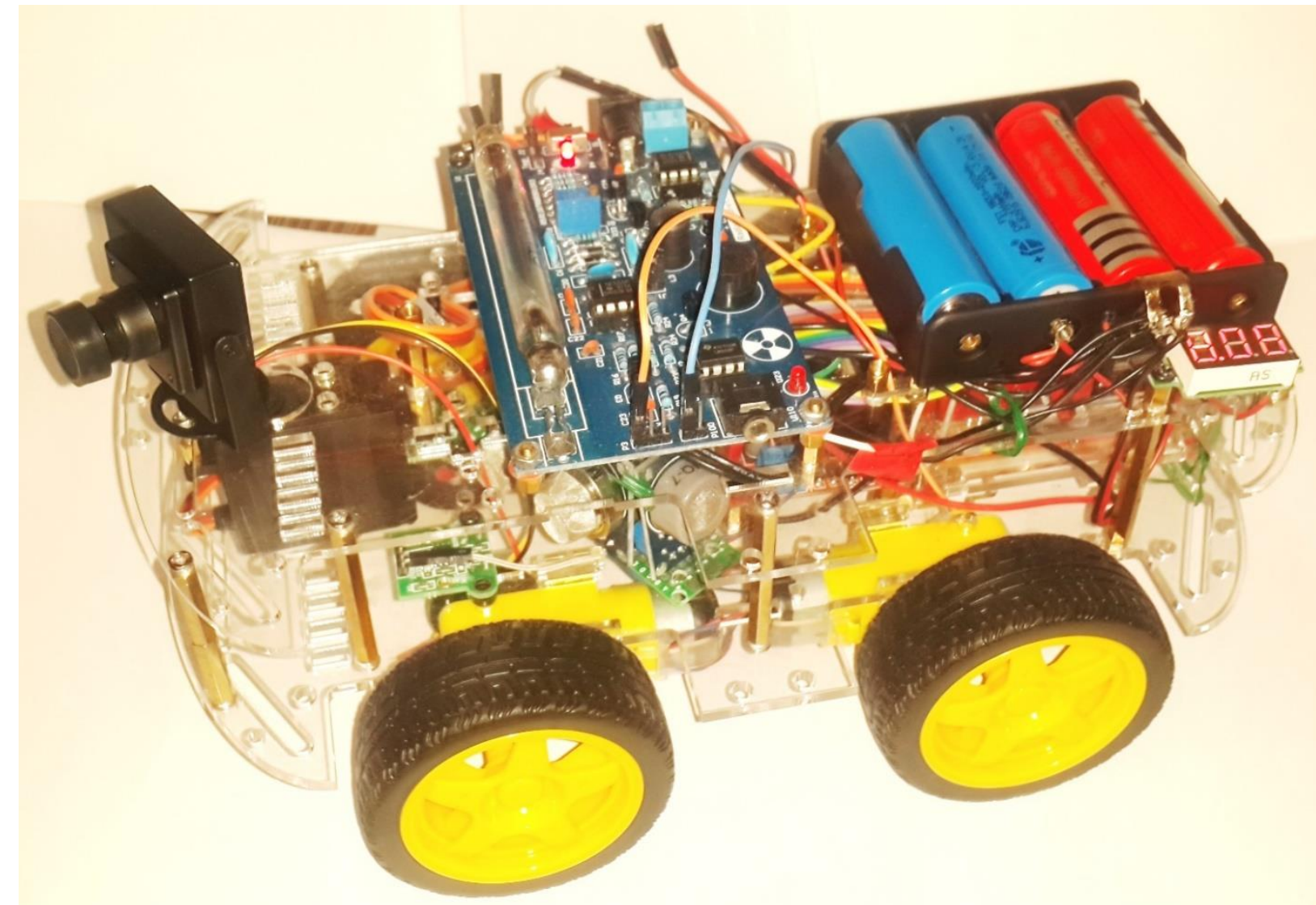

Picture 4 - The developed model of the robot for radiation reconnaissance. 


\begin{tabular}{|c|c|c|c|c|c|c|}
\hline Impact Factor: & $\begin{array}{l}\text { ISRA (India) } \\
\text { ISI (Dubai, UAE } \\
\text { GIF (Australia) } \\
\text { JIF }\end{array}$ & $\begin{array}{l}=1.344 \\
=0.829 \\
=0.564 \\
=1.500\end{array}$ & $\begin{array}{l}\text { SIS (USA) } \\
\text { PИНЦ (Russia } \\
\text { ESJI (KZ) } \\
\text { SJIF (Morocco }\end{array}$ & $\begin{array}{r}=\mathbf{0 . 9 1 2} \\
=\mathbf{0 . 2 3 4} \\
=\mathbf{1 . 0 4 2} \\
=\mathbf{2 . 0 3 1}\end{array}$ & $\begin{array}{l}\text { ICV (Poland) } \\
\text { PIF (India) } \\
\text { IBI (India) }\end{array}$ & $\begin{array}{l}=6.630 \\
=1.940 \\
=4.260\end{array}$ \\
\hline
\end{tabular}

\section{Conclusion}

The result of this study, created the robot and algorithms for robot movement, and also we can make the following conclusions:

- Developed robotic search engine for objects contaminated by radiation.

- Created an Autonomous robot with remote control.

- Studied the work of the radiation sensor.
- Developed algorithms to alert the operator of the robot about the radiation danger.

- Developed algorithms tested

- Defines the maximum speed of the robot is $1.4 \mathrm{~m} / \mathrm{s}$

- Defines the maximum angular speed of the robot $150 \% \mathrm{sec}$

- The resulting algorithms are efficient and can have a practical application in robotics for radioactive contamination and radiation leakage.

\section{References:}

1. Galimyanov Ruslan Failevich (2017) The path planning of wheeled robot for noisy measurements in the problem of controlling movement along a curved trajectory. Thesis in the Technosphere: Available: http://tekhnosfera.com/planirovanie-puti-

kolesnogo-robota-po-zashumlennymizmereniyam-v-zadache-upravleniyadvizheniem-vdol-krivolineynoytraekt\#ixzz3yoc9pRqi (Accessed: 1.03.2017).

2. Freire Carrera, Fausto Rodrigo (2017) the Study of dynamics of controlled motion of wheeled mobile robot along a predetermined path.

3. (2017) Implementation of the wheeled vehicle along a predetermined path - page 22 . Available:

http://vestniken.ru/articles/250/html/files/assets/ basic-html/page22.html (Accessed: 1.03.2017)

4. Pavlovsky VE, Evgrafov VV, Pavlovskii VV, Petrovskaya NI (2017) Dynamics, modeling, control of mobile robots. Available: http://www.umlab.ru/index/download/evgrafov ¿ipm.pdf (Accessed: 1.03.2017).

5. Pesterev AV, Rapoport LB (2017) CONSTRUCTION Of INVARIANT ELLIPSOIDS IN the STABILIZATION PROBLEM of the MOTION of a WHEELED ROBOT ALONG a CURVED PATH. Available:

http://stab12.ipu.ru/stab10/08/documents/PR/Pesterev-Rapoport.pdf (Accessed: 1.03.2017).
6. Vasiliev Ivan Anatol'evich (2017) SaintPetersburg, TSNII RTK, head of lab. Ph. D. CONSTRUCTION of TRAJECTORIES FOR a MOBILE ROBOT

7. (2017) Uniformly accelerated motion. Available:

https://yandex.kz/images/search?text=pавноуск оренное $\% 20$ движение\&img url=http $\% 3 \mathrm{~A} \% 2$ F\%2F900igr.net\%2Fdatas\%2Ffizika\%2FRazdel y-mekhaniki\%2F0030-030-Prjamolinejnoeravnouskorennoe-

dvizhenie.jpg\&pos=0\&rpt=simage \&stype $=$ ima ge\&lr=21094\&noreask=1\&source=wiz

(Accessed: 1.03.2017).

8. (2017) MINI ROBOT ON ARDUINO UNO. Available: http://arduinokit.ru/arduino/arduinoprojects/introducing-our-mini-robot-onarduino-part-3.html (Accessed: 1.03.2017).

9. (2017) Description of the motion of a mobile robot.

Available: http://robotosha.ru/robotics/robot-motion.html (Accessed: 1.03.2017).

10. (2017) Arduino. Finished project "Robotmachine RoboCar4W". Available: http://tim4dev.com/arduino-instruction-projectrobocar4w/ (Accessed: 1.03.2017).

11. (2014) Ready Arduino robots. Available: http://edurobots.ru/2014/04/gotovye-arduinoroboty/ (Accessed: 1.03.2017).

12. (2017) CARduino - a homemade robot Arduino. Available: http://cxem.net/uprav/uprav23.php (Accessed: 1.03.2017). 